\title{
Assessing the role of two populations of Aedes japonicus japonicus for Zika virus transmission under a constant and a fluctuating temperature regime
}

\author{
Uros Glavinic ${ }^{1,2}$, Jasmin Varga ${ }^{1}$, Anca loana Paslaru', Jeannine Hauri ${ }^{1}$, Paul Torgerson ${ }^{3}$, Francis Schaffner ${ }^{1,4}$ \\ and Eva Veronesi ${ }^{1 *}$
}

\begin{abstract}
Background: Since the huge epidemic of Zika virus (ZIKV) in Brazil in 2015, questions were raised to understand which mosquito species could transmit the virus. Aedes aegypti has been described as the main vector. However, other Aedes species (e.g. Ae. albopictus and Ae. japonicus) proven to be competent for other flaviviruses (e.g. West Nile, dengue and yellow fever), have been described as potential vectors for ZIKV under laboratory conditions. One of these, the Asian bush mosquito, Ae. japonicus, is widely distributed with high abundances in central-western Europe. In the present study, infection, dissemination and transmission rates of ZIKV (Dak84 strain) in two populations of Ae. japonicus from Switzerland (Zürich) and France (Steinbach, Haut-Rhin) were investigated under constant $\left(27^{\circ} \mathrm{C}\right)$ and fluctuating $\left(14-27^{\circ} \mathrm{C}\right.$, mean $\left.23^{\circ} \mathrm{C}\right)$ temperature regimes.
\end{abstract}

Results: The two populations were each able to transmit ZIKV under both temperature regimes. Infectious virus particles were detected in the saliva of females from both populations, regardless of the incubation temperature regime, from 7 days post-exposure to infectious rabbit blood. The highest amount of plaque forming units (PFU) (400/ml) were recorded 14 days post-oral infection in the Swiss population incubated at a constant temperature. No difference in terms of infection, dissemination and transmission rate were found between mosquito populations. Temperature had no effect on infection rate but the fluctuating temperature regime resulted in higher dissemination rates compared to constant temperature, regardless of the population. Finally, transmission efficiency ranged between 7-23\% and $7-10 \%$ for the constant temperature and $0-10 \%$ and 3-27\% under fluctuating temperatures for the Swiss and the French populations, respectively.

Conclusions: To the best of our knowledge, this is the first study confirming vector competence for ZIKV of Ae. japonicus originating from Switzerland and France at realistic summer temperatures under laboratory conditions. Considering the continuous spread of this species in the northern part of Europe and its adaptation at cooler temperatures, preventative control measures should be adopted to prevent possible ZIKV epidemics.

Keywords: Aedes japonicus, Fluctuating temperature, Vector competence, Zika virus

*Correspondence: eva.veronesi@uzh.ch

${ }^{1}$ National Centre for Vector Entomology, Institute of Parasitology,

Vetsuisse Faculty, University of Zürich, Zürich, Switzerland

Full list of author information is available at the end of the article

c) The Author(s) 2020. This article is licensed under a Creative Commons Attribution 4.0 International License, which permits use, sharing, adaptation, distribution and reproduction in any medium or format, as long as you give appropriate credit to the original author(s) and the source, provide a link to the Creative Commons licence, and indicate if changes were made. The images or other third party material in this article are included in the article's Creative Commons licence, unless indicated otherwise in a credit line to the material. If material is not included in the article's Creative Commons licence and your intended use is not permitted by statutory regulation or exceeds the permitted use, you will need to obtain permission directly from the copyright holder. To view a copy of this licence, visit http://creativeco mmons.org/licenses/by/4.0/. The Creative Commons Public Domain Dedication waiver (http://creativecommons.org/publicdomain/ zero/1.0/) applies to the data made available in this article, unless otherwise stated in a credit line to the data. 


\section{Background}

The first appearance of the invasive bush mosquito Aedes (Hulecoeteomyia) japonicus japonicus (Theobald 1901) (Diptera: Culicidae) in Europe was in 2000 [1] in France. In 2008, Ae. japonicus was first detected in Switzerland [2], in the north-west part of the country from where it spread and became widely established with locally high abundances. Recently, the species has established in other European countries [2] such as Austria, Croatia, Germany, Hungary, Italy, Liechtenstein, The Netherlands, Slovenia and Spain [3-8].

According to genetic studies of the populations collected in Europe, it has been postulated that two separate introductions of Ae. japonicus resulted in the presence of two genotypes (genotype I and II) $[9,10]$. The first genotype includes populations from Belgium and southwestern Germany/Switzerland, eastern Austria/Slovenia and southeastern Germany/ northwestern Austria whereas genotype II includes specimens from western and northern Germany only $[10,11]$.

The role of this species as putative vector of arboviruses such as Eastern equine encephalitis virus (EEEV) [12], La Crosse encephalitis virus (LACV) [13], West Nile virus (WNV) [14, 15], dengue virus (DENV), chikungunya virus (CHIKV) [16] and filarial parasites [17] has been well described. Since the large outbreak of Zika virus (ZIKV) in South America [18] in 2015, huge attention has been given to investigate which mosquito species could be involved in its transmission [19] and how this can vary between vector populations and virus strains [20-23]. Several Aedes species have been proven to be capable of transmitting ZIKV [24] including autochthonous and invasive European species (Ae. albopictus) [25-27]. Although Ae. aegypti has been described as the main vector species for ZIKV transmission [24], recent studies have also shown the potential role of an Ae. japonicus population from southwestern Germany in the transmission of a ZIKV strain from Guatemala (Central America) [26].

Our recent findings have confirmed the potential role of a population of Ae. japonicus from Switzerland for the transmission of flaviviruses such as WNV, CHIKV and DENV [14, 15]. ZIKV belongs to the same family as WNV and DENV, therefore it was pertinent to investigate the transmission potential of Ae. japonicus for ZIKV. The effect of different temperatures on the infection, dissemination and transmission of ZIKV for a German population of Ae.japonicus, was also investigated in the work of Jansen et al. [26]. However, although the authors have demonstrated transmission occurring at $27^{\circ} \mathrm{C}$, they used constant temperature regimes and not fluctuating which would have been a more realistic reflect of the natural field conditions of variable temperatures. Consequently, we wished to also investigate if transmission varied according to temperature regime and population of Ae. japonicus.

In our study, we have tested one strain of ZIKV from Dakar (DAK84 Senegal, Africa) [27] with populations of Ae. japonicus from Switzerland (Zürich) and France (Steinbach, Haut-Rhin). Several vector competence indices from orally infected Ae. japonicus females were investigated: infection (virus presence in abdomen-thorax); dissemination (virus presence in head); transmission (virus presence in saliva), and transmission efficiency (females with positive saliva among tested females). Two major aims were addressed: (i) to determine the susceptibility to oral infection with ZIKV of two field-collected Ae. japonicus populations; and (ii) to evaluate how fluctuating $v s$ constant temperature is affecting the susceptibility to ZIKV infection, dissemination and transmission within these Ae. japonicus populations.

\section{Methods \\ Mosquito rearing}

Field-collected Ae. japonicus were used for this study. Eggs were collected with standard ovitraps baited with germination paper as oviposition substrate [26]. Two different localities were chosen for collection. The first was located in Zürich, Switzerland, with two collection sites, the Schwamendingen cemetery $\left(47^{\circ} 24^{\prime} 5^{\prime \prime} \mathrm{N}\right.$, $\left.8^{\circ} 34^{\prime} 28^{\prime \prime} \mathrm{E}\right)$ and a private garden close to the University of Zürich - Irchel Campus $\left(47^{\circ} 23^{\prime} 45.3^{\prime \prime} \mathrm{N}, 8^{\circ} 33^{\prime} 04.6^{\prime \prime} \mathrm{E}\right)$. The second location was a private garden $\left(47^{\circ} 49^{\prime} 16.02^{\prime \prime} \mathrm{N}\right.$, $7^{\circ} 8^{\prime} 59.20^{\prime \prime} \mathrm{E}$ ) in Steinbach (Haut-Rhin, France). Overall, 30 ovitraps were placed in Zürich (10 in the private garden and 20 in the cemetery) and 20 in Steinbach during June-August 2017. Germination papers were changed weekly, stored semi-dry in plastic zip bags for 7 days at room temperature and then placed in plastic trays with $2 \mathrm{l}$ of deionized water. One day post-immersion, hatched larvae were counted, split (400 larvae/tray) and supplemented with yeast tablets (Gayelord Hauser Superlevure, Gayelord Hauser, France) as larval food (2 tablets/tray). If necessary, half a tablet was added few days later. Larvae were incubated at $27{ }^{\circ} \mathrm{C}$ with $85 \%$ relative humidity (RH) and the adults obtained were kept into polyester cubic netted cages $(32.5 \times 32.5 \times 32.5 \mathrm{~cm})$ (Bugdorm 43030F, MegaViewScienceCo. Ltd., Taichung, Taiwan) under long daylight conditions (16:8 h L:D) including $1 \mathrm{~h}$ dusk and 1 h dawn. A $10 \%$ sucrose solution was provided daily to the adults as carbohydrate source.

\section{Mosquito infection}

Lyophilized ZIKA virus Dak84 strain, isolated in Dakar (GenBank: KU955592 [27]) (7.57 $\left.\log _{10} \mathrm{TCID}_{50} / \mathrm{ml}\right)$ and 
provided by Dr Failloux (Institute Pasteur, Paris, France). The virus was re-suspended into $400 \mu$ lof distilled water, then mixed (1:3) with washed heparinized rabbit blood (not older than $24 \mathrm{~h}$ ) obtained from the slaughterhouse of a private company (H. R. Kyburz AG, Dorfstrasse 32, Lupfig, Switzerland) to obtain a final a titer of $7.1 \log _{10}$ $\mathrm{TCID}_{50} / \mathrm{ml}$. Finally, phagostimulant (ATP at $5 \times 10^{-3}$ M) was added to each blood meal. Seven to 9 days-old females were deprived of sugar $24 \mathrm{~h}$ before their exposure to virus-spiked blood as previously described [14]. Briefly, immediately after the preparation of the infectious blood mixture, $3 \mathrm{ml}$ were transferred into a Hemotek feeder (Hemotek Ltd., Lancashire, UK) and covered with a pork intestine membrane fixed with a rubber ring. Mosquitoes were aspirated from the rearing cages and transferred into $500 \mathrm{ml}$ plastic bottles (c.60 females/bottle) with the top side covered with a fine net through which the mosquitoes were exposed to the Hemotek feeder. After 20 min of exposure to the infectious blood, mosquitoes were anesthetized by placing the bottles at $-20{ }^{\circ} \mathrm{C}$ for about 4-5 min and then transferred onto a Petri dish previously layered with filter paper. The Petri dish was kept on an ice pack the whole time to keep the mosquitoes anesthetized. Fully engorged females were collected and placed into a cardboard box cylinder $(12 \mathrm{~cm}$ diameter and $15 \mathrm{~cm}$ length) covered with nets at both sides which in turn was allocated into a bugdorm cage. Freshly engorged mosquitoes (two females/experiment) were collected immediately after blood-feeding (Day 0 ) as well as a small aliquot of the infectious inoculum for further analysis. All the engorged females were incubated under two different climatic conditions: (i) constant temperature $\left(27^{\circ} \mathrm{C}\right.$ and relative humidity $85 \%$ ); and (ii) fluctuating temperature $\left(21 \pm 7{ }^{\circ} \mathrm{C}\right.$ (mean $23{ }^{\circ} \mathrm{C}$ ) with $45-90 \%$ relative humidity), reflecting a typical day in northern Switzerland in mid-summer (www.meteoswiss.admin.ch). The photoperiod for both temperatures was the same as described above. Accordingly, there were four different groups of engorged mosquitoes: Steinbach (i) at constant and (ii) fluctuating temperature; Zürich (iii) at constant and (iv) fluctuating temperature. At different time points (days 7 , 14 and 21 post-oral feeding), 30 females from each infection group were collected. Cardboard boxes were placed at $-20{ }^{\circ} \mathrm{C}$ for $4-5 \mathrm{~min}$ to anesthetize the survived mosquitoes after which they were transferred onto a Petri dish with an ice pack as described above and processed for virus detection. From each time point collection we investigated the rate of infection (IR, proportion of females with infected abdomen among tested females), dissemination (DR, proportion of females with infected heads among infected females), transmission (TR, proportion of females with infected saliva among the females with disseminated infection) and transmission efficiency
(TE, proportion of females with infectious saliva among all tested females). All feeding, manipulation and incubation of ZIKV infected mosquitoes were carried out at biosafety containment level 3 (BSL3).

\section{Virus detection in abdomen (infection) and head (dissemination)}

After the incubation period, females were dissected for removal of wings and legs with sterile forceps and the rest of the body (head, abdomen and thorax) stored dry in $1.5 \mathrm{ml}$ Eppendorf tubes at $-80{ }^{\circ} \mathrm{C}$ until further investigation. Infection and virus dissemination, confirmed by the presence of virus particles in the tissues of abdomen and thorax (body) and heads, respectively, was determined from body parts' homogenates. A Tissue Lyser ${ }^{\circledR}$ II instrument (Qiagen, Hilden, Germany) was used for homogenization, at $25 \mathrm{~Hz}$ for $1 \mathrm{~min}$, followed by $5 \mathrm{~min}$ centrifugation at $13,000 \times g$ at $4{ }^{\circ} \mathrm{C}$ as described [14]. Briefly, $300 \mu \mathrm{l}$ of Eagle's Minimum Essential Medium (EMEM) (LGC Standard, GmbH, Wesel, Germany) supplemented with $1 \%$ antibiotics and fungizone (1000 $\mathrm{IU} / \mathrm{ml}$ penicillin/streptomycin; $4 \mu \mathrm{g} / \mathrm{ml}$ amphotericin) (Gibco, Thermo Fisher Scientific, Reinach, Switzerland) (EMEM complete), 2\% fetal bovine serum (FBS), and one stainless steel bead ( $3 \mathrm{~mm}$ diameter) were added to each tube containing either the head or the body of the individual mosquitoes. 96-well plates layered with Vero cells (30,000 cells/100 $\mu \mathrm{l} /$ well) and EMEM complete supplemented with $10 \%$ FCS were prepared 1 day prior to Vero cell infection, and incubated at $37^{\circ} \mathrm{C}$ with $5 \% \mathrm{CO}_{2}$. When cells were $75-80 \%$ confluent, medium was removed and $100 \mu \mathrm{l}$ of serial dilutions of body part homogenates (neat, 1:10 and 1:100) was inoculated into the monolayer of Vero cells. After the incubation period, cells were stained with a crystal violet solution $(0.2 \%$ of crystal violet, $10 \%$ formaldehyde and $10 \%$ ethanol) in order to identify positive wells. Briefly, $2 \mathrm{ml}$ of the crystal violet solution was added to each well followed by $30 \mathrm{~min}$ incubation at room temperature after which the wells were washed twice with deionized water and the presence of viral particle assessed by detection of cytopathic effects (CPE) under a microscope. The whole body of day 0 females was also homogenized and titrated to confirm virus titre. Briefly, a serial dilution $(1: 10,1: 100,1: 1000,1: 10,000$ and 1:100,000) was loaded on a 96-well plate layered with Vero cells as described above for the abdomen, thorax and heads. After a 7-day incubation, cells were checked and titre calculated based on the presence of plaques.

Virus detection and quantification in saliva (transmission) For saliva collection, after the removal of wings and legs from each survived individual, the proboscis was inserted into $20 \mu \mathrm{l}$ pipette tips filled with $5 \mu \mathrm{l}$ of FBS. After 30 
min salivation, the $5 \mu \mathrm{l}$ of FBS with collected saliva were transferred into $1.5 \mathrm{ml}$ Eppendorf tubes containing $45 \mu \mathrm{l}$ of EMEM complete, giving a final volume of $50 \mu$ l. Saliva was held on ice until all the samples were collected and then frozen at $-80^{\circ} \mathrm{C}$.

The quantification of infectious virus particles was determined by a plaque forming unit assay and expressed as PFU/saliva. Briefly, 6-well plates layered with $75-80 \%$ confluent Vero cells $(800,000$ cells/2 $\mathrm{ml} /$ well) were inoculated with EMEM complete supplemented with $10 \%$ FBS $24 \mathrm{~h}$ before incubation with saliva. For the infection, the medium was removed from each well and $265 \mu \mathrm{l}$ of EMEM complete supplemented with $2 \%$ FBS was added to each well, followed by $35 \mu \mathrm{l}$ of the saliva sample giving a total volume of $300 \mu \mathrm{l} /$ well. The remaining $15 \mu \mathrm{l}$ of the saliva samples were kept at $-80{ }^{\circ} \mathrm{C}$ as a back-up. After $1 \mathrm{~h}$ incubation at $37^{\circ} \mathrm{C}, 4 \mathrm{ml}$ of a $0.5 \%$ agarose solution (UltraPure ${ }^{\mathrm{TM}}$ Agarose, Invitrogen Life Technologies, Renfrew, UK) in EMEM complete was added to each well without the removal of the inoculum, and all plates incubated at $37{ }^{\circ} \mathrm{C}$ with $5 \% \mathrm{CO}_{2}$. At day 7 post-incubation, the agarose gel was removed and cells were stained by adding $2 \mathrm{ml}$ of crystal violet solution per well. After $30 \mathrm{~min}$ incubation at room temperature, cells were rinsed with water and plaques enumerated according to the volume of the sample tested and expressed as PFU/saliva.

\section{Statistical analysis}

Differences in the rates of infection, dissemination, and transmission between the two temperature conditions (fluctuating, $21 \pm 7^{\circ} \mathrm{C}$; and constant, $27^{\circ} \mathrm{C}$ ) and the two populations of Ae. japonicus were analysed by logistic regression.

There were therefore three logistic regression models. The first considered infection of mosquitoes as a binomial dependent variable (virus detected in the abdomen as infected or no virus detected as not infected). The independent variables were site (categorical variable, France or Zürich), time (continuous variable $n$ days postoral feeding) and temperature (categorical variable, constant or fluctuating).

The second logistic regression model considered only those mosquitoes in which infection was proven. In this case dissemination was the dependent variable (virus detected in the head as disseminated or not disseminated).

The third logistic regression model only considered those mosquitoes in which there was dissemination of virus. The detection of virus in the saliva (transmission) was the dependent binomial variable (positive or negative). The same independent variables for the first logistic regression model were used in the second and third regression model. Interactions between independent variables were also analysed. All proportions (infected/ not infected, disseminated/not disseminated, infectious/not infectious) are reported with exact 95\% binomial confidence intervals. The association of viral growth (copy number) with time or temperature was analysed using a negative binomial generalized linear model (GLM) with a log link function. This assumed that copy number was an integer dependent variable, with a minimum value of zero that was overdispersed. Hence the negative binomial model was considered the most appropriate model for analysis. For all regression models, backward stepwise elimination was used to remove non-significant variables in the model. All possible interactions in the models were also examined. Regression models were also undertaken taking data from the two sites in separate models for an insight into variables that may only have an association at one of the two study sites. Significant variables remaining within models are reported as the $P$-value and corresponding $Z$-statistic. All analyses were undertaken in R [16].

\section{Results \\ Mosquito infection}

Overall, 2460 Ae. japonicus females were exposed to blood spiked with the ZIKV Dak84 strain, with a final titer of $7.0 \log _{10} \mathrm{TCID}_{50} / \mathrm{ml}$, and a total of 739 individuals (450 from Zürich and 289 from Steinbach) were successfully engorged (feeding rates 8-33\%).

\section{Virus detection in abdomen (infection) and head (dissemination)}

Infection rates (IR) (Table 1), based on the cytopathic effect (CPE) on Vero cells, for the Zürich population of Ae. japonicus incubated at a constant temperature, ranged between 83-93\% (Additional file 1: Figure S1) whereas the rates for mosquitoes incubated at fluctuating temperatures were $17-77 \%$. Similarly, the infection rate of the Steinbach population ranged between $67-100 \%$ at a constant temperature, and $47-73 \%$ at fluctuating temperature (Table 2) (Additional file 1: Figure S1). Logistic regression analyses showed that there were no significant differences in the rates of infection between the two populations of Ae. japonicus and in the infection rate according to the incubation temperature (fluctuating $v s$ constant temperature) and the length of incubation post oral infection (day 7, 14 or 21).

Within the Zürich population $(n=121)$, dissemination rate $(\mathrm{DR})$ was higher $(Z=2.339, d f=118$, $P=0.019)$ when females were incubated at a fluctuating temperature compared to constant temperature, ranging between $26-71 \%$ and $12-40 \%$ (Additional 


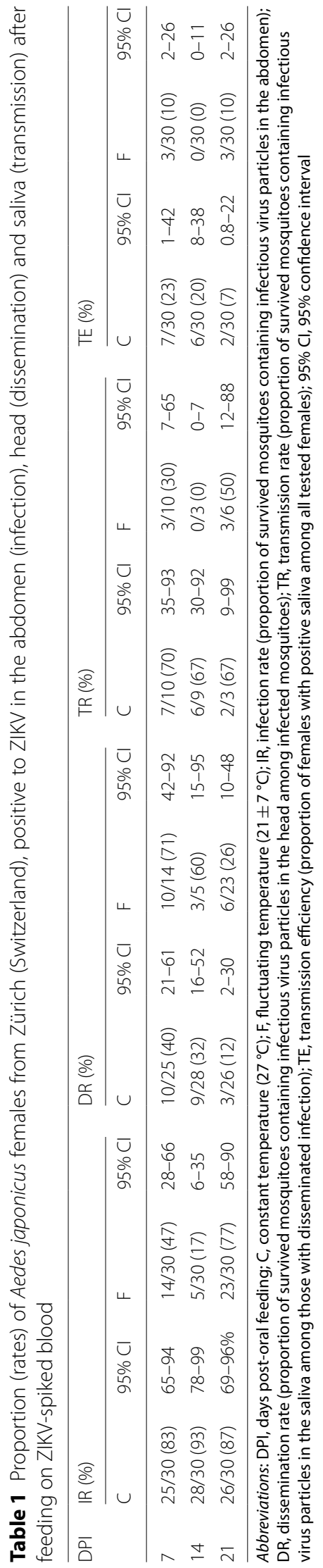


file 1: Figure S1), respectively, whereas DR decreased over time (length of incubation 7,14 and 21 days) $(Z=-3.409, d f=118, P=0.0067)$ regardless of the incubation temperature regimes. Within the Steinbach population $(n=122)$ of Ae. japonicus there was an interaction between fluctuating temperature and time with an increased dissemination rate over time under fluctuating temperature conditions $(Z=2.612, d f=118$, $P=0.009)(32-64 \%)$ but not if incubated at a constant temperature (20-40\%).

Viral titer among females collected straight after oral infection (day 0 females) ranged between 4.25-5.25 $\log _{10}$ $\mathrm{PFU} / \mathrm{ml}$.

\section{Virus detection and quantification in the saliva (transmission)}

Infectious virus particles were detected in the saliva of females from both populations incubated at either constant or fluctuating temperature regimes. No statistical differences were found in the transmission rate between the two populations and between the two temperature regimes. However, transmission rates for mosquitoes which originated from Steinbach $(n=122)$ and incubated at a fluctuating temperature were significantly higher at 14 days post-incubation compared to those after 21 days $(Z=-2.432, d f=71, P=0.015)$.

The transmission rate (TR) varied between $67-70 \%$ and $30-50 \%$ in the Zürich population and $25-50 \%$ and $11-73 \%$ rate (Additional file 1: Figure S1) for the Steinbach population at constant and fluctuating temperature, respectively (Table 1 ). Positive saliva samples were observed already at day 7 post-oral infection regardless of incubation conditions and origin of the population.

No significant differences were observed for the saliva viral load (number of infectious virus particles/female) according to incubation temperature regime and time in both populations (Fig. 1). There was no statistical evidence for differences in transmission efficiency (TE) (Table 1) between the Zürich population (7-23\%) incubated at constant temperature $\left(27^{\circ} \mathrm{C}\right)$ compared to the Steinbach population (7-10\%) incubated at the same temperature (Additional file 1: Figure S1). Likewise, there was no statistical evidence for differences between the two populations in their TE at fluctuating temperatures. As shown in Fig. 1, saliva titres from disseminated females ranged from 1.4 to $440 \mathrm{PFU} /$ saliva, with the maximum titre recorded for one Ae. japonicus female originated from Zürich and incubated for 14 days at a constant temperature.

\section{Discussion}

To the best of our knowledge, this is the first study exploring the vector competence of Ae. japonicus for ZIKV under a fluctuating temperature regime [24]. Our results confirm the potential role of Ae. japonicus for ZIKV transmission under laboratory conditions. Moreover, higher dissemination rates were observed for the population from Zürich when incubated under a fluctuating temperature regime $\left(21 \pm 7^{\circ} \mathrm{C}\right)$.

Previous studies investigating mosquito vector competence for several pathogens have been carried out under constant temperature regimes, testing several temperature sets to understand the lower degree threshold for virus infections, dissemination and transmission [26, 28-33]. The main concern of running vector competence studies using a constant temperature for incubation of infected arthropods is that this is not mimicking the real situation in the field where mosquitoes are constantly exposed to fluctuating temperatures. Since arthropods cannot thermoregulate, environmental temperatures play a crucial role on both the ecology and the vectorial capacity of arthropod vectors, affecting parameters such as mortality rate, length of the gonotrophic cycle, biting rate, etc.

Temperature has also a large impact on the amplification of pathogens inside the arthropod body. The length of time required for a pathogen to reach the salivary gland after the intake of an infectious blood meal, the socalled extrinsic incubation period (EIP), is indeed largely regulated by temperature [32, 33]. A correlation between the EIP and temperature is described, with higher temperatures increasing the speed of viral replication, infection and transmission (shorter EIP). Lower temperatures increase the length of the EIP, with an implication for the efficiency of being a vector [30, 34]. However, most of the time the correlation between EIP and temperature has been demonstrated under laboratory conditions where commonly constant temperatures were applied and not fluctuating ones. Some studies on Culex species infected with WNV have shown that fluctuating temperature regime have no impact on the rate of the EIP compared to constant mean daily temperatures [34, 35]. However, recent papers have actually demonstrated that even under a fluctuating temperature regime, vector competence can be influenced by a large $\left(20^{\circ} \mathrm{C}\right)$ or moderate $\left(10{ }^{\circ} \mathrm{C}\right)$ diurnal temperature range (DTR) is [36]. Lambrechts et al. [36] described a lower midgut infection at large DTR compared to midgut infection observed under moderate DTR for Ae. aegypti infected with two DENV serotypes, despite average temperatures being the same $\left(26^{\circ} \mathrm{C}\right)$.

In our study, a fluctuating temperature regime with a DTR of $14{ }^{\circ} \mathrm{C}$ and a mean of $23^{\circ} \mathrm{C}$ was shown to increase 


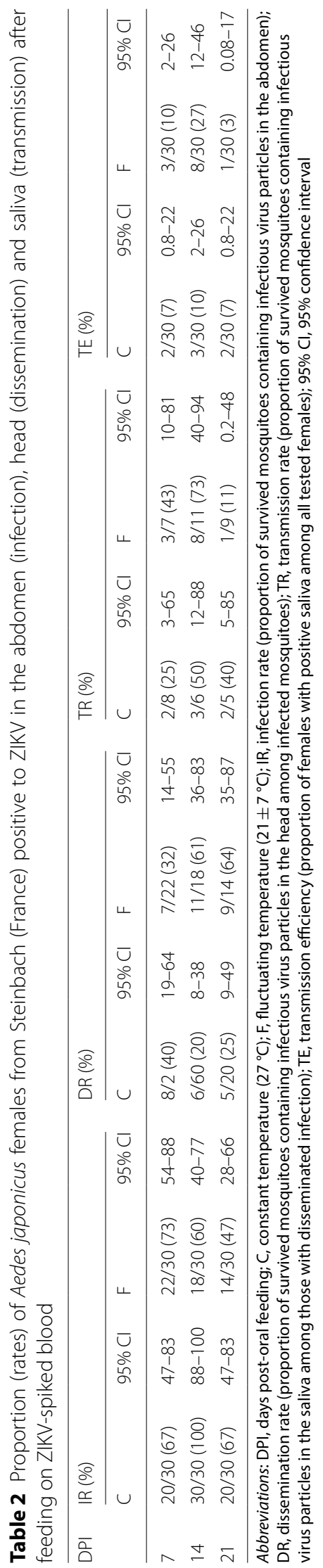




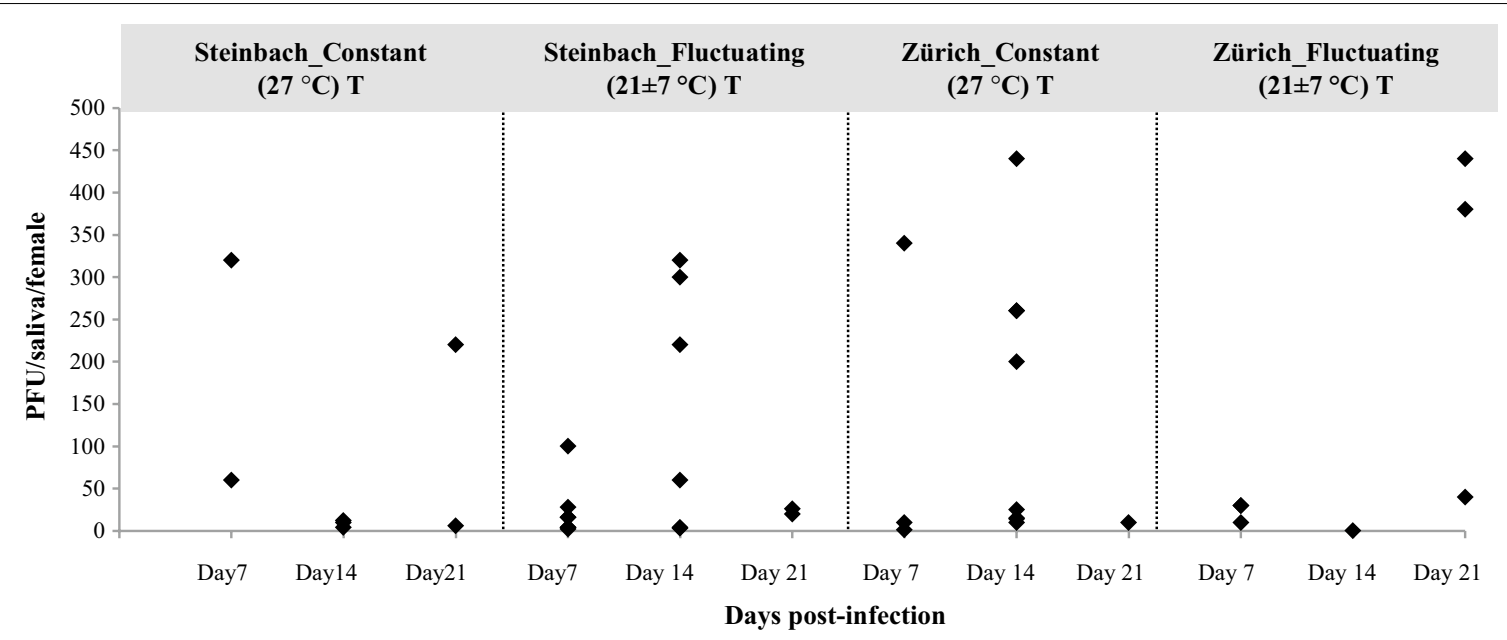

Fig. 1 Viral loads of females orally fed with ZIKV-spiked blood. Data are given as PFU/female according to their origin (Zürich and Steinbach) and temperature condition, constant $\left(27^{\circ} \mathrm{C}\right)$ vs fluctuating $\left(21 \pm 7^{\circ} \mathrm{C}\right)$ for an incubation period of 7,14 and 21 days

virus dissemination rate compared to a constant temperature of $27{ }^{\circ} \mathrm{C}$ among ZIKV-infected Ae. japonicus regardless of the population used. The decrease in the dissemination rate over time recorded here in both populations (except for the French population when incubated at a fluctuating temperature) was also described for other vectors when infected with Zika or dengue virus [37,38]. We could speculate that dissemination barriers present in the haemocoel of these mosquitoes are very efficient, though to confirm this further studies should be carried out.

Overall, no significant differences for infection, transmission and dissemination were observed between the two populations, although they both show the potential to transmit the ZIKV strain tested here. Further investigations on the genetic make-up of the two populations are here suggested to better clarify their relatedness. These results are in contrast with a recent study investigating ZIKV transmission for a population of Ae. japonicus from Germany, where three temperatures were tested (constant 21,24 and $27{ }^{\circ} \mathrm{C}$ ) for an incubation period of 14 days. In this study [26], transmission was observed only at $27^{\circ} \mathrm{C}$. Dissemination was detected at 24 and $27^{\circ} \mathrm{C}$ with the highest rate at $24{ }^{\circ} \mathrm{C}$ but a higher virus titer at $27^{\circ} \mathrm{C}$. Midgut infection was recorded at all the three temperatures with the lowest rate at $21{ }^{\circ} \mathrm{C}$.

Although in our study we have recorded transmission of ZIKV at a mean temperature of $23^{\circ} \mathrm{C}$, we can infer that, in the German population, other parameters must have been involved in preventing dissemination of the virus within the mosquito. Indeed, it is not the first time that the Swiss population (Zürich) of Ae. japonicus has been shown to be more competent than a population from Germany
(Stuttgart) [11] when exposed to the same virus (WNV) $[14,15,39]$. In this previous study [39], the population from Germany was completely negative for WNV infection after 14 days post-oral exposure to infectious blood. On the other hand, another population of the same species originating from the USA [40] was found capable of WNV transmission under laboratory conditions when incubated at $26{ }^{\circ} \mathrm{C}$. The authors have speculated that differences in genetic background between Ae. japonicus populations from Germany and North America are most likely responsible for the differences in vector competence for WNV [39]. Indeed, vector competence is controlled by several factors including the genetic background of the mosquito species which can vary between different populations and the pathogen strain used [41]. We can consider that the Swiss, the French and the German populations of Ae. japonicus were derived from the same introduction since they were collected from a continuous colonized area, probably originating from Switzerland [2]. Genetic analyses of German and Swiss populations of $A e$. japonicus have described the Swiss population as more closely related to the population from southern Germany (Waldshut-Tiengen, Baden-Württemberg) rather than to the northern population from Bonn [39]. Thus, the different susceptibility to virus transmission between the Swiss and the southern Germany (Stuttgart) populations might not be a genetically driven effect. Clearly, more investigations are required to assess the influence of the type of assay used, general methodologies applied during the experiments and the strain of ZIKV used for oral infection. In our study we have used a highly virulent ZIKV strain (DAK84, GenBank: KU955592) [27, 42] from Senegal, very closely related to another strain (GenBank: KU955591) 
originating from the same area (Dakar, Senegal) [41, 42] that has previously demonstrated to be successfully transmitted by Ae. aegypti under laboratory conditions [43]. The study by Jansen et al. [26] was carried out using a strain from Guatemala (Mexico) (GenBank: KU870645) [43] closely related to another ZIKV strain (GenBank: KX247632) [44] which has already been shown to be not very infectious for mosquitoes, since Ae. aegypti originating from Brazil and USA orally exposed to this strain were negative in the saliva [24, 45]. However, a very recent paper has shown efficient transmission among Ae. aegypti infected with another strain of ZIKV isolated from fieldinfected mosquitoes originating from Mexico although no sequencing of this strain was carried out [46].

As we have demonstrated here, the pathogen-vector interaction and consequences for virus transmission is a very complex aspect that needs to be considered carefully when assessing vector competence of a mosquito species. The data here presented were produced using mosquitoes infected and handled under laboratory conditions. When assessing vector competence of mosquito species in the transmission of a specific pathogen in the field, other factors (e.g. vector abundance, longevity, biting rate and dispersal) influencing the efficiency of pathogen transmission should also being taken in consideration.

In the present study, we have shown that two populations of Ae. japonicus from the western part of Europe (Switzerland and France) are potentially capable of transmitting ZIKV at realistic fluctuating temperatures between 14 and $27{ }^{\circ} \mathrm{C}$ with a mean of $23{ }^{\circ} \mathrm{C}$ suggesting that there is a risk for ZIKV transmission in these areas and that preventative measures to control the spread and suppress populations of the invasive Ae. japonicus should be implemented.

\section{Conclusions}

Our study confirms that, under laboratory conditions, both investigated populations of Ae. japonicus could potentially transmit Zika virus under a central European summer temperature regime. Although no differences were detected in infection, dissemination and transmission rates among the two populations for the two temperature regimes, we proved that dissemination increases when mosquitoes are incubated under a fluctuating temperature compared to constant one. More attention should be given to the strain of virus used and the population of mosquitoes exposed to these strains in order to evaluate the impact that the genetic make-up of both the virus and the vectors can have on vector competence, and the consequent implications for the onset of ZIKV epidemics in Europe.

\section{Supplementary information}

Supplementary information accompanies this paper at https://doi. org/10.1186/s13071-020-04361-2.

Additional file 1: Figure S1. Rates of infection, dissemination and transmission for two populations (Zürich and Steinbach) of Ae.japonicus incubated at two different temperatures (constant $27^{\circ} \mathrm{C}$ and fluctuating $\left.21 \pm 7^{\circ} \mathrm{C}\right)$.

\section{Abbreviations}

WNV: West Nile virus; EEEV: Eastern equine encephalitis virus; LCV: La Cross virus; DENV: Dengue virus; CHIKV: Chikungunya virus; ZIKV: Zika virus; Vero: Vero cells, African green monkey kidney cells; EMEM: Eagle's minimum essential medium; FCS: Foetal calf serum; CPE: Cytopathic effect; $\mathrm{TCID}_{50} / \mathrm{ml}$ : 50\% tissue culture infectious dose; IR: Infection rate; DR: Dissemination rate; TR: Transmission rate; Dpi: Days post-infection; BSL3: Biosafety security level 3; LASC: Laboratory Animal Service Centre; PFU: Plaque-forming unit; GLM: Generalized linear model.

\section{Acknowledgements}

We kindly thank Alexander Mathis (Institute of Parasitology, Zürich, Switzerland) for valuable comments on the manuscript, Anna-Bella Failloux (Institut Pasteur, Paris, France) for providing the Zika virus in the frame of the European Union's Horizon 2020 Research and Innovation Programme under ZIKAlliance Grant Agreement no. 734548. The authors are very grateful to the Animal Laboratory Service Centre (LASC) at Irchel, University of Zürich, to make available the BSL3 facility. We highly acknowledge the Bundesamt für Lebensmittelsicherheit und Veterinärwesen (Switzerland) for financial support of the National Centre for Vector Entomology.

\section{Authors' contributions}

EV conceived and designed the study. UG and JV collected mosquitoes in the field in Zürich, performed laboratory rearing of mosquitoes, oral infection and processed samples. AP was involved in mosquito oral infections, saliva collection and dissection. JH processed samples and carried out mosquito rearing. PT carried out the statistical analyses. FS provided eggs from Steinbach. EV and UG analysed the results and drafted the manuscript. All authors read and approved the final manuscript.

\section{Funding}

The study was funded by the Staatssekretariat für Bildung Forschung und Innovation (SBFI, CH) Vertragsnummer 17.0009-1 as a contribution to the participation of the research project ZIKAlliance in the frame of the European Union's Horizon 2020 Research and Innovation Programme (ZIKAlliance 734548).

\section{Availability of data and materials}

The datasets used and/or analyzed during the present study are available from the corresponding author upon reasonable request. All data generated or analysed during this study are included in this published articles and its additional file.

\section{Ethics approval and consent to participate}

Not applicable.

\section{Consent for publication}

Not applicable.

\section{Competing interests}

The authors declare that they have no competing interests.

\section{Author details}

${ }^{1}$ National Centre for Vector Entomology, Institute of Parasitology, Vetsuisse Faculty, University of Zürich, Zürich, Switzerland. ${ }^{2}$ Department of Biology, Faculty of Veterinary Medicine, University of Belgrade, Belgrade, Serbia. ${ }^{3}$ Section of Epidemiology, Vetsuisse Faculty, University of Zürich, Zürich, Switzerland.

${ }^{4}$ Francis Schaffner Consultancy, Lörracherstrasse 50, 4125 Riehen, Switzerland. 
Received: 9 March 2020 Accepted: 11 September 2020

Published online: 18 September 2020

\section{References}

1. Schaffner F, Chouin S, Guilloteau J. First record of Ochlerotatus (Finlaya) japonicus japonicus (Theobald, 1901) in metropolitan France. J Am Mosa Control Assoc. 2003:19:1-5.

2. Schaffner F, Kaufmann C, Hegglin D, Mathis A. The invasive mosquito Aedes japonicus in central Europe. Med Vet Entomol. 2009;23:448-51.

3. Seidel B, Nowotny N, Bakonyi T, Allerberger F, Schaffner F. Spread of Aedes japonicus japonicus (Theobald, 1901) in Austria, 2011-2015, and first records of the subspecies for Hungary, 2012, and the principality of Liechtenstein, 2015. Parasit Vectors. 2016;9:356.

4. Ibáñez-Justicia A, Kampen H, Braks M, Schaffner F, Steeghs M, Werner D, et al. First report of established population of Aedes japonicus japonicus (Theobald, 1901) (Diptera, Culicidae) in the Netherlands. J Eur Mosa Control Assoc. 2014;32:9-13.

5. Klobucar A, Lipovac I, Zagar N, Mitrovic-Hamzic S, Tesic V, Vilibic-CavlekT, et al. First record and spreading of the invasive mosquito Aedes japonicus japonicus (Theobald, 1901) in Croatia. Med Vet Entomol. 2019;33:171-6.

6. Versteirt V, Schaffner F, Garros C, Dekoninck W, Coosemans M, Van Bortel W. Introduction and establishment of the exotic mosquito species Aedes japonicus japonicus (Diptera: Culicidae) in Belgium. J Med Entomol. 2009:46:1464-7.

7. Scholte EJ, Schaffner F. Waiting for the tiger: establishment and spread of the Aedes albopictus mosquito in Europe. In: Takken W, Knols BGJ, editors. Emerging pests and vector-borne diseases in Europe, vol. 1. Wageningen: Wageningen Academic Publishers; 2007. p. 241-60

8. Dalla Pozza G, Majori G. First record of Aedes albopictus establishment in Italy. J Am Mosq Control Assoc. 1992;8:318-20.

9. Koban MB, Kampen H, Scheuch DE, Frueh L, Kuhlisch C, Janssen N, et al. The Asian bush mosquito Aedes japonicus japonicus (Diptera: Culicidae) in Europe, 17 years after its first detection, with a focus on monitoring methods. Parasit Vectors. 2019;12:109.

10. Zielke DE, Werner D, Schaffner F, Kampen H, Fonseca DM. Unexpected patterns of admixture in German populations of Aedes japonicus japonicus (Diptera: Culicidae) underscore the importance of human intervention. PLoS ONE. 2014;9:e99093.

11. Zielke DE, Ibanez-Justicia A, Kalan K, Merdic E, Kampen H, Werner D. Recently discovered Aedes japonicus japonicus (Diptera: Culicidae) populations in The Netherlands and northern Germany resulted from a new introduction event and from a split from an existing population. Parasit Vectors. 2015;8:40

12. Sardelis MR, Dohm DJ, Pagac B, Andre RG, Turell MJ. Experimental transmission of eastern equine encephalitis virus by Ochlerotatus j.japonicus (Diptera: Culicidae). J Med Entomol. 2002;39:480-4.

13. Sardelis MR, Turell MJ, Andre RG. Laboratory transmission of La Crosse virus by Ochlerotatus jjaponicus (Diptera: Culicidae). J Med Entomol. 2002:39:635-9.

14. Veronesi E, Paslaru A, Silaghi C, Tobler K, Glavinic U, Torgerson P, et al. Experimental evaluation of infection, dissemination, and transmission rates for two West Nile virus strains in European Aedes japonicus under a fluctuating temperature regime. Parasitol Res. 2018;117:1925-32.

15. Wagner S, Mathis A, Schonenberger AC, Becker S, Schmidt-Chanasit J, Silaghi $C$, et al. Vector competence of field populations of the mosquito species Aedes japonicus japonicus and Culex pipiens from Switzerland for two West Nile virus strains. Med Vet Entomol. 2018;32:121-4.

16. R Development Core Team. R: A language and environment for statistical computing. Vienna: R Foundation for Statistical Computing; 2014. http:// www.R-project.org/.

17. Schaffner F, Vazeille M, Kaufmann C, Failloux AB, Mathis A. Vector competence of Aedes japonicus for chikungunya and dengue viruses. Eur Mosq Bull. 2011;29:141-2.

18. Silaghi C, Beck R, Capelli G, Montarsi F, Mathis A. Development of Dirofilaria immitis and Dirofilaria repens in Aedes japonicus and Aedes geniculatus. Parasit Vectors. 2017;10:94
19. Zanluca C, Melo VC, Mosimann AL, Santos Gl, Santos CN, Luz K. First report of autochthonous transmission of Zika virus in Brazil. Mem Inst Oswaldo Cruz. 2015;110:569-72.

20. Boyer S, Calvez E, Chouin-Carneiro T, Diallo D, Failloux AB. An overview of mosquito vectors of Zika virus. Microbes Infect. 2018;20:646-60.

21. Pompon J, Morales-Vargas R, Manuel M, Huat Tan C, Vial T, Hao Tan J, et al. A Zika virus from America is more efficiently transmitted than an Asian virus by Aedes aegypti mosquitoes from Asia. Sci Rep. 2017;7:1215.

22. Ciota AT, Bialosuknia SM, Zink SD, Brecher M, Ehrbar DJ, Morrissette MN, et al. Effects of Zika virus strain and Aedes mosquito species on vector competence. Emerg Infect Dis. 2017;23:1110-7.

23. Hery L, Boullis A, Delannay C, Vega-Rua A. Transmission potential of African, Asian and American Zika virus strains by Aedes aegypti and Culex quinquefasciatus from Guadeloupe (French West Indies). Emerg Microbes Infect. 2019;8:699-706.

24. Chouin-Carneiro T, Vega-Rua A, Vazeille M, Yebakima A, Girod R, Goindin D, et al. Differential susceptibilities of Aedes aegypti and Aedes albopictus from the Americas to Zika virus. PLoS Negl Trop Dis. 2016;10:e0004543.

25. Heitmann A, Jansen S, Luhken R, Leggewie M, Badusche M, Pluskota B, et al. Experimental transmission of Zika virus by mosquitoes from central Europe. Euro Surveill. 2017;22:30437.

26. Jansen $\mathrm{S}$, Heitmann A, Luhken R, Jost H, Helms M, Vapalahti O, et al. Experimental transmission of Zika virus by Aedes japonicus japonicus from southwestern Germany. Emerg Microbes Infect. 2018;7:192.

27. Atieh T, Baronti C, de Lamballerie X, Nougairede A. Simple reverse genetics systems for Asian and African Zika viruses. Sci Rep. 2016;6:39384.

28. Vogels CB, Fros JJ, Goertz GP, Pijlman GP, Koenraadt CJ. Vector competence of northern European Culex pipiens biotypes and hybrids for West Nile virus is differentially affected by temperature. Parasit Vectors. 2016;9:393

29. Leggewie M, Badusche M, Rudolf M, Jansen S, Borstler J, Krumkamp R, et al. Culex pipiens and Culex torrentium populations from central Europe are susceptible to West Nile virus infection. One Health. 2016;2:88-94.

30. Kilpatrick AM, Meola MA, Moudy RM, Kramer LD. Temperature, viral genetics, and the transmission of West Nile virus by Culex pipiens mosquitoes. PLoS Pathog. 2008;4:e1000092.

31. Reisen WK, Fang Y, Martinez VM. Effects of temperature on the transmission of West Nile virus by Culex tarsalis (Diptera: Culicidae). J Med Entomol. 2006;43:309-17.

32. Chamberlain RW, Sudia WD. Mechanism of transmission of viruses by mosquitoes. Annu Rev Entomol. 1961;6:371-90.

33. Hardy JL, Houk EJ, Kramer LD, Reeves WC. Intrinsic factors affecting vector competence of mosquitoes for arboviruses. Annu Rev Entomol. 1983;28:229-62.

34. Danforth ME, Reisen WK, Barker CM. The impact of cycling temperature on the transmission of West Nile virus. J Med Entomol. 2016:53:681-6.

35. Cornel AJ, Jupp PG, Blackburn NK. Environmental temperature on the vector competence of Culex univittatus (Diptera: Culicidae) for West Nile virus. J Med Entomol. 1993:30:449-56.

36. Lambrechts L, Paaijmans KP, Fansiri T, Carrington LB, Kramer LD, Thomas $\mathrm{MB}$, et al. Impact of daily temperature fluctuations on dengue virus transmission by Aedes aegypti. Proc Natl Acad Sci USA. 2011;108:7460-5.

37. Boccolini D, Toma L, Di Luca M, Severini F, Romi R, Remoli ME, et al. Experimental investigation of the susceptibility of Italian Culex pipiens mosquitoes to Zika virus infection. Euro Surveill. 2016;21:30328.

38. Xiao FZ, Zhang Y, Deng YQ, He S, Xie HG, Zhou XN, et al. The effect of temperature on the extrinsic incubation period and infection rate of dengue virus serotype 2 infection in Aedes albopictus. Arch Virol. 2014;159:3053-7.

39. Huber K, Jansen S, Leggewie M, Badusche M, Schmidt-Chanasit J, Becker $\mathrm{N}$, et al. Aedes japonicus japonicus (Diptera: Culicidae) from Germany have vector competence for Japan encephalitis virus but are refractory to infection with West Nile virus. Parasitol Res. 2014:113:3195-9.

40. Turell MJ, O'Guinn ML, Dohm DJ, Jones JW. Vector competence of North American mosquitoes (Diptera: Culicidae) for West Nile virus. J Med Entomol. 2001;38:130-4.

41. Vazeille M, Zouache K, Vega-Rua A, Thiberge JM, Caro V, Yebakima A, et al. Importance of mosquito "quasispecies" in selecting an epidemic arthropod-borne virus. Sci Rep. 2016;6:29564. 
42. Ladner JT, Wiley MR, Prieto K, Yasuda CY, Nagle E, Kasper MR, et al. Complete genome sequences of five Zika virus isolates. Genome Announc. 2016:4:e00377.

43. Driggers RW, Ho CY, Korhonen EM, Kuivanen S, Jaaskelainen AJ, Smura T, et al. Zika virus infection with prolonged maternal viremia and fetal brain abnormalities. N Engl J Med. 2016;374:2142-51.
44. Dupont-Rouzeyrol M, Diancourt L, Calvez E, Vandenbogaert M, O'Connor $\mathrm{O}$, Teissier A, et al. Zika virus evolution on the edges of the Pacific Ocean. Emerg Microbes Infect. 2017;6:e111.

45. Roundy CM, Azar SR, Rossi SL, Huang JH, Leal G, Yun R, et al. Variation in Aedes aegypti mosquito competence for Zika virus transmission. Emerg Infect Dis. 2017;23:625-32.

46. Elizondo-Quiroga D, Ramirez-Medina M, Gutierrez-Ortega A, ElizondoQuiroga A, Munoz-Medina JE, Sanchez-Tejeda G, et al. Vector competence of Aedes aegypti and Culex quinquefasciatus from the metropolitan area of Guadalajara, Jalisco, Mexico for Zika virus. Sci Rep. 2019;9:16955.

\section{Publisher's Note}

Springer Nature remains neutral with regard to jurisdictional claims in published maps and institutional affiliations.
Ready to submit your research? Choose BMC and benefit from:

- fast, convenient online submission

- thorough peer review by experienced researchers in your field

- rapid publication on acceptance

- support for research data, including large and complex data types

- gold Open Access which fosters wider collaboration and increased citations

- maximum visibility for your research: over 100M website views per year

At BMC, research is always in progress.

Learn more biomedcentral.com/submissions 